medRxiv preprint doi: https://doi.org/10.1101/2021.10.27.21265567; this version posted October 28, 2021. The copyright holder for this preprint (which was not certified by peer review) is the author/funder, who has granted medRxiv a license to display the preprint in It is made available under a CC-BY-NC-ND 4.0 International license.

\title{
The effects of maternal pre-pregnancy BMI, pregnancy smoking and alcohol consumption on molar-incisor hypomineralisation: A negative control study
}

\author{
Qui-Yi Lim ${ }^{1}$, Kurt Taylor ${ }^{2}$, Tom Dudding ${ }^{1}$ \\ 1. University of Bristol Dental School \\ 2. University of Bristol Medical School
}

Corresponding Author: Qui-Yi Lim, Email: q116941@ @ristol.ac.uk

Total word count: 3877 (excluding figures and tables) 
medRxiv preprint doi: https://doi.org/10.1101/2021.10.27.21265567; this version posted October $28,2021$. The copyright holder for this preprint (which was not certified by peer review) is the author/funder, who has granted medRxiv a license to display the preprint in It is made available under a CC-BY-NC-ND 4.0 International license

\section{ACKNOWLEDGEMENTS}

We are extremely grateful to all the families who took part in this study, the midwives for their help in recruiting them, and the whole ALSPAC team, which includes interviewers, computer and laboratory technicians, clerical workers, research scientists, volunteers, managers, receptionists and nurses.

\section{FUNDING}

The UK Medical Research Council and Welcome (Grant ref: 217065/Z/19/Z) and the University of Bristol provide core support for ALSPAC. A comprehensive list of grants funding is available on the ALSPAC website (http://www.bristol.ac.uk/alspac/external/documents/grant-acknowledgements.pdf). This publication is the work of the authors and Qui-Yi Lim, Kurt Taylor and Tom Dudding will serve as guarantors for the contents of this paper. Qui-Yi Lim is supported by INSPIRE, the Academy of Medical Sciences (AMS) and the Welcome Trust. Kurt Taylor is supported by a British Heart Foundation Doctoral Training Program (FS/17/60/33474). Tom Dudding is funded as an Academic Clinical Fellow by the National Institute for Health Research.

\section{CONFLICT OF INTEREST}

The authors declare no conflict of interest.

\section{DATA AVAILABILITY}

The data that support the findings form this study are available from the ALSPAC cohort (http://www.bristol.ac.uk/alspac/) but restrictions apply to the availability of these data, which were used under license for the current study, and so are not publicly available. Data are however available upon reasonable request and with permission of ALSPAC executive. 
medRxiv preprint doi: https://doi.org/10.1101/2021.10.27.21265567; this version posted October 28,2021 . The copyright holder for this preprint (which was not certified by peer review) is the author/funder, who has granted medRxiv a license to display the preprint in It is made available under a CC-BY-NC-ND 4.0 International license .

\section{ABBREVIATIONS}

ALSPAC - Avon longitudinal study of adults and children

BMI - Body mass index

CI - Confidence interval

FPM - First permanent molars

MIH - Molar-incisor hypomineralisation

$\mathbf{O R}$ - Odds ratio

\section{ABSTRACT}

\section{Objectives}

(1) To explore the associations between modifiable maternal pregnancy exposures: prepregnancy body mass index (BMI), pregnancy smoking and alcohol consumption with offspring molar-incisor hypomineralisation (MIH).

(2) To explore for the presence of residual confounding using negative control analyses.

\section{Methods}

This study used data from Avon Longitudinal Study of Parents and Children (ALSPAC), a UK prospective birth cohort. We defined offspring MIH using prospectively collected questionnaire data. We used logistic regression to explore confounder adjusted associations between maternal pre-pregnancy BMI and smoking and alcohol consumption during pregnancy with MIH. We included negative control exposure (paternal BMI, smoking and alcohol around the time of pregnancy) and outcome (offspring dental trauma) analyses to explore for the presence of residual confounding.

\section{Results}

5536 mother/offspring pairs were included (297 MIH cases [5.4\%]). We found a positive association between maternal mean BMI and offspring MIH (OR per 1-kg/m² difference in maternal BMI: 1.04, 95\% CI: 1.00, 1.08). In subsequent analyses, we found evidence that this effect was non-linear and being driven by women in the highest BMI quintiles. In negative control analyses, we found no evidence of association between paternal BMI and offspring MIH (OR: 0.94, 95\% CI: 0.89, 1.00) and maternal BMI and offspring dental trauma (OR: 0.99, 95\% CI: 0.96, 1.02). There was no clear evidence of an association for maternal pregnancy smoking (OR: 0.76, 95\%CI: 0.46, 1.22) and alcohol consumption (OR: 0.79, 95\% CI: $0.56,1.21)$ with offspring MIH with results imprecisely estimated. 
medRxiv preprint doi: https://doi.org/10.1101/2021.10.27.21265567; this version posted October 28, 2021. The copyright holder for this preprint (which was not certified by peer review) is the author/funder, who has granted medRxiv a license to display the preprint in It is made available under a CC-BY-NC-ND 4.0 International license.

\section{Conclusion}

In summary we found evidence of a possible intrauterine effect of high maternal prepregnancy BMI on offspring MIH. We did not find robust evidence for an intrauterine effect of maternal pregnancy smoking or alcohol consumption on offspring MIH. Our findings provide further support for women of reproductive age to maintain a healthy weight. Future studies are warranted to explore possible mechanisms on how the pregnancy environment may relate to offspring $\mathrm{MIH}$.

\section{KEY WORDS}

\section{ALSPAC}

Molar-incisor hypomineralisation

Body mass index

Smoking

Alcohol

Negative control 
medRxiv preprint doi: https://doi.org/10.1101/2021.10.27.21265567; this version posted October 28,2021 . The copyright holder for this preprint (which was not certified by peer review) is the author/funder, who has granted medRxiv a license to display the preprint in It is made available under a CC-BY-NC-ND 4.0 International license .

\section{INTRODUCTION}

Molar-incisor hypomineralisation (MIH) is a developmental, qualitative enamel defect caused by reduced mineralisation and inorganic enamel components. It primarily affects one or more first permanent molars (FPMs), and frequently involves incisors (1) and occasionally canines as well (2). MIH is often diagnosed around 6-7 years of age when the FPMs and central incisors erupt into the oral cavity. Due to the poor quality enamel, affected teeth present aesthetically concerning with discoloured creamy-white or yellow-brown demarcations (1). These teeth also carry pathological concerns as they are often hypersensitive, susceptible to post-eruptive breakdown (3) and rapid caries progression (4). Consequently, MIH teeth often have poor prognosis and are frequently extracted before adulthood $(5,6)$. As such, MIH presents a great demand on healthcare systems; the likelihood of children with MIH to return to clinic for dental treatment has been found to be 10.5 times greater than those without (7).

The exact prevalence of MIH is unclear. Estimates vary between 2.4 and 40.2\%, with a global mean of $13.1 \%$ (95\% confidence interval (CI): 11.8, 14.5) (8). The literature remains inconclusive around the aetiology of $\mathrm{MIH}$; however, it is generally accepted that causes are likely to be multifactorial. Many studies propose a genetic predisposition $(9,10)$ however, the clinical presentation of these localised, asymmetrical lesions indicate a further cause of systemic or environmental origin which disrupts enamel formation. The development of FPMs begins in utero and continues to develop 2-3 years after birth $(11,12)$. With this prolonged developmental time window, a range of prenatal, perinatal, and post-natal factors have been investigated. These include maternal illness (13), low offspring birth weight (14), childhood antibiotic exposure (15) and many more. Despite FPMs developing in utero there is little research on maternal exposures during pregnancy.

To our knowledge, there have been no studies that have investigated the effect of maternal body mass index (BMI) on MIH. Maternal pre-pregnancy obesity is known to affect foetal development $(16,17)$. FPMs develop in utero, therefore, it is plausible that changes in BMI may influence dental development. Effects of pregnancy smoking and alcohol consumption have been well established with birth defects associated with craniofacial and dental abnormalities, such as oral facial clefts for smoking (18), and foetal alcohol syndrome for alcohol $(19,20)$. Effects of pregnancy smoking and alcohol on MIH have also been 
medRxiv preprint doi: https://doi.org/10.1101/2021.10.27.21265567; this version posted October 28,2021 . The copyright holder for this preprint (which was not certified by peer review) is the author/funder, who has granted medRxiv a license to display the preprint in It is made available under a CC-BY-NC-ND 4.0 International license .

investigated. However, recent systematic reviews on these risk factors concluded that there is no significant evidence to show an association with $\mathrm{MIH}(21,22)$. Conversely, the primary literature exists to be conflicting and the strength of evidence is limited. Previous studies have been limited due to a lack of detail and consistency in the maternal exposures and MIH outcomes investigated (21) which makes comparisons between studies difficult. Many studies have also failed to adjust for confounding variables and include relatively small numbers in analyses (e.g., $\mathrm{N}=12-31$ for smoking analyses, $\mathrm{N}=8$ for alcohol analyses). Furthermore, these studies predominantly use retrospective study designs which are prone to common epidemiological biases, such as recall bias. Therefore, we cannot determine whether these reflect the magnitude of the causal effect, or if these results are biased by residual confounding, systematic reporting bias or measurement bias.

Negative controls are often used in epidemiology to test for causal intrauterine effects and detect for potential residual confounding after adjusting for measured confounders (23). There are two types of negative control experiments: a negative control exposure, shown in Figure 1A, and a negative control outcome, shown in Figure 1B (23). The idea of these negative control experiments is to substitute a condition with an exposure or outcome variable that (i) shares similar confounding structures as the 'real study' (the original association), and (ii) does not have a plausible biological link with the association of interest (24). Under these two assumptions, it can be assumed that the 'real study' and negative control experiment are perfectly comparable, and we can therefore expect results of the negative controls to produce a weaker or no association if there were to be a true causal effect (23). In this study, we used paternal exposures measured around the time of pregnancy as a negative exposure control. Parental negative exposure controls have been used previously to explore the intrauterine effects of maternal exposures and offspring outcomes $(25,26)$. The assumptions of this approach are that: (i) measured and unmeasured confounders influence the exposures in the same direction and with a similar magnitude in mothers and fathers and (ii) there is no plausible reason why the exposure in the father would affect the offspring outcome (or at a minimum the paternal association would be much weaker than in the mother) (Figure 1A). We used offspring dental trauma as a negative outcome control under the assumptions that: (i) offspring dental trauma shares similar confounding structures to offspring MIH and (ii) maternal exposures during pregnancy could not plausibly cause offspring dental trauma. 
medRxiv preprint doi: https://doi.org/10.1101/2021.10.27.21265567; this version posted October 28, 2021. The copyright holder for this preprint (which was not certified by peer review) is the author/funder, who has granted medRxiv a license to display the preprint in It is made available under a CC-BY-NC-ND 4.0 International license.

In summary, the exact causes of MIH are unclear and intrauterine factors via maternal pregnancy exposures could be relevant. There is a need for more prospective research using study designs that are reliably able to assess the presence of confounding. Identifying modifiable risk factors for $\mathrm{MIH}$ is important for improving aetiological understanding and developing preventive interventions to reduce disease burden.

The aims of this study were to:

1) Explore associations between maternal pre-pregnancy BMI, pregnancy smoking and alcohol consumption with offspring MIH.

2) Explore for the presence of residual confounding using both negative control exposure and outcome analyses. 
medRxiv preprint doi: https://doi.org/10.1101/2021.10.27.21265567; this version posted October 28, 2021. The copyright holder for this preprint (which was not certified by peer review) is the author/funder, who has granted medRxiv a license to display the preprint in perpetuity.

It is made available under a CC-BY-NC-ND 4.0 International license

\section{A: NEGATIVE CONTROL EXPOSURE ANALYSES}
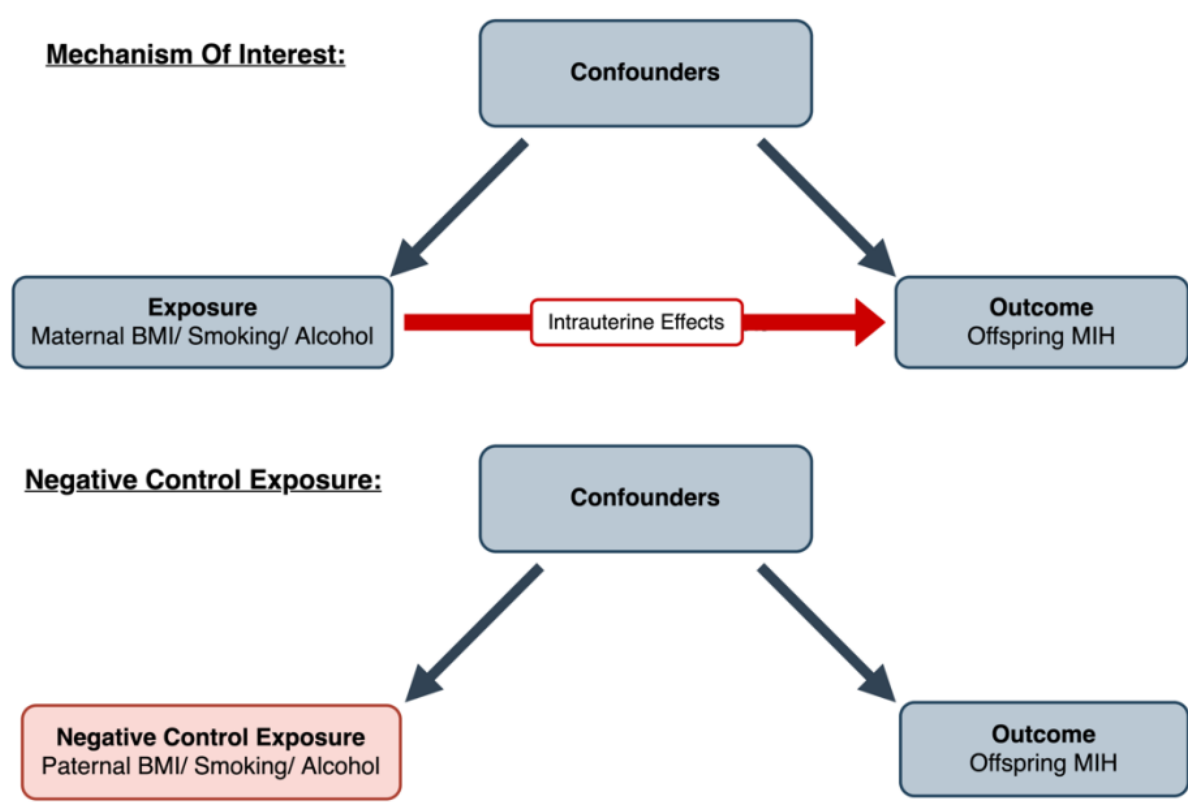

\section{B: NEGATIVE CONTROL OUTCOME ANALYSES}

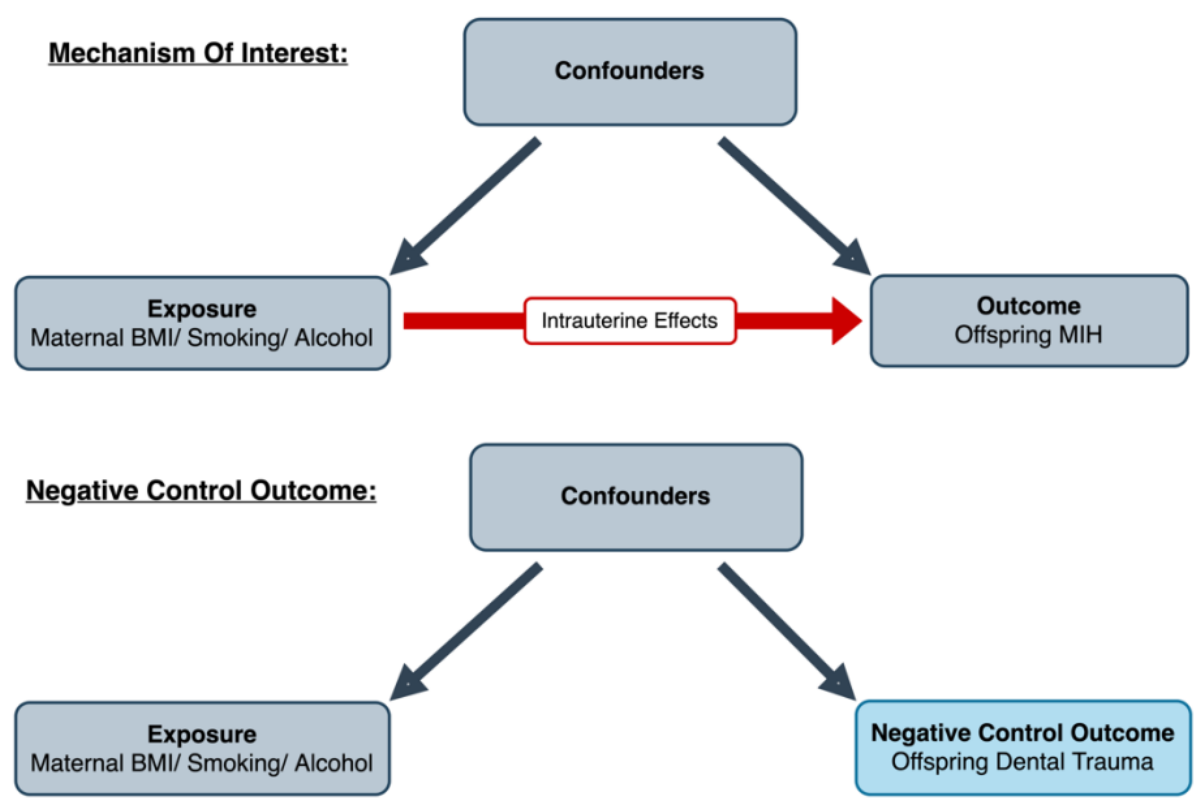

Figure 1: Diagrams to show negative control experiments. 1A shows how a negative control exposure, paternal BMI/ smoking/ alcohol can be used to investigate effects of intrauterine exposures on MIH birth outcomes. The paternal exposure has the same incoming arrows as the maternal exposure of interest, but has no arrow to the offspring MIH outcome - this means that any association observed between the paternal exposure and MIH outcome of interest will be due to the confounding variables in the model. 1B shows how a negative control outcome, offspring dental trauma can be used to investigate effects of intrauterine exposures on MIH birth outcomes. Offspring dental trauma has the same incoming arrows as the MIH outcome of interest, but has no arrow from the maternal exposure of interest - this means that any association observed between the maternal exposure and offspring dental trauma will be due to the confounding variables in the model. Each exposure variable (maternal and paternal BMI, smoking and alcohol consumption) and outcome variable (offspring MIH and dental trauma) will be looked at separately. 
medRxiv preprint doi: https://doi.org/10.1101/2021.10.27.21265567; this version posted October 28,2021 . The copyright holder for this preprint (which was not certified by peer review) is the author/funder, who has granted medRxiv a license to display the preprint in It is made available under a CC-BY-NC-ND 4.0 International license .

\section{METHODS}

\subsection{Data}

We used data from Avon Longitudinal Study of Parents and Children (ALSPAC), an ongoing, multigenerational, prospective birth cohort study. 14541 pregnant women residing in Avon, UK with expected delivery dates between $1^{\text {st }}$ April 1991 and 31 ${ }^{\text {st }}$ December 1992 were recruited. Two further rounds of recruitment totalled 15454 pregnant women and 14 901 offspring alive at 1 year of age were enrolled in the study (Figure 2) (27, 28).

Participants have been regularly followed up through questionnaires and clinic visits at the time of pregnancy in the mothers and fathers, and subsequent offspring from early life through to adulthood. Please note that the study website contains details of all the data that is available through a fully searchable data dictionary and variable search tool (http://www.bristol.ac.uk/alspac/researchers/our-data/). Ethical approval for the study was obtained from the ALSPAC Ethics and Law Committee and Local Research Ethics Committees.

\subsection{Participant inclusion criteria}

At age 7 and 10, participants completed self-report questionnaires on dental health, with assistance from their parents and use of a mirror. A subset of participants who had: (i) completed the questionnaire and (ii) had at least one first permanent molar tooth through by age 7 were included in this study. In total, 5,536 mother-offspring pairs were included. The flow of participants through the study are illustrated in Figure 2.

\subsection{Exposures}

\section{Primary exposure: Maternal BMI, smoking and alcohol consumption}

Maternal BMI was calculated using self-reported pre-pregnancy weight and height using data from the questionnaire completed around 12 weeks' gestation. For the main analyses, BMI was used as a continuous variable. Maternal pregnancy smoking was measured by quantifying the number of times smoked per day in each trimester, obtained through selfreport questionnaires completed at 18 weeks' and 32 weeks' gestation. For analyses, available data from each trimester was categorised into binary variables (yes/no), and used to generate one variable, categorised as "any pregnancy smoking" (yes/no). For maternal pregnancy alcohol consumption, data was only available for the first and third trimester, from the questionnaires completed at 18 weeks' and 32 weeks' gestation. Here, mothers were 
medRxiv preprint doi: https://doi.org/10.1101/2021.10.27.21265567; this version posted October 28,2021 . The copyright holder for this preprint (which was not certified by peer review) is the author/funder, who has granted medRxiv a license to display the preprint in It is made available under a CC-BY-NC-ND 4.0 International license .

asked often they consumed alcoholic drinks, measured in glasses per week. This was used to generate one binary variable, "any alcohol consumption" (yes/no). The rationale for including all three trimesters for pregnancy smoking and alcohol consumption is because the development of the FPMs begins in utero; initiation of the tooth germ begins 3.5-4 months in utero, hard tissue formation occurs around 7-8 months after ovulation, and the start of calcification occurs at birth $(11,12)$. Therefore, it is plausible that the intrauterine environment throughout the entire pregnancy could influence offspring MIH.

\section{Negative control exposures: Paternal BMI, smoking and alcohol consumption}

We used paternal BMI, smoking and alcohol consumption during pregnancy as negative control exposures. Paternal BMI was calculated using self-reported weight and height at the 18 weeks' gestation questionnaire and used as a continuous variable. Partner's self-reported smoking and alcohol was recorded at around 18 weeks' gestation. Paternal smoking habits were measured using questions regarding the number of times partners smoked at the start of pregnancy. This was defined as a binary variable, "any partner smoking” (yes/no). Paternal alcohol consumption during pregnancy was measured using questions asking how often they consumed alcoholic drinks in the past 3 months, measured in glasses per week. This was also defined as a binary variable "any alcohol consumption" (yes/no).

\subsection{Outcomes}

\section{Primary outcome: Offspring MIH}

We defined MIH by using questions related to the child's " 6 -year molars" from the age 7 and 10 self-report questionnaires. With the available data from the age 7 questionnaire, cases of MIH were primarily defined as any child with at least one FPM that came through looking brown. This was classified as a binary outcome, "any MIH" (yes/no).

\section{Negative control outcome: Offspring dental trauma}

We used offspring dental trauma as a negative control outcome. Questions related to "accidents to your teeth" from the questionnaire answered at age 10 were used. Dental trauma was defined as any child whose teeth became "loose", "chipped" or "knocked out" when they 
medRxiv preprint doi: https://doi.org/10.1101/2021.10.27.21265567; this version posted October $28,2021$. The copyright holder for this preprint (which was not certified by peer review) is the author/funder, who has granted medRxiv a license to display the preprint in It is made available under a CC-BY-NC-ND 4.0 International license

banged their top adult teeth. This negative control outcome was defined as binary, "any dental trauma" (yes/no).

\subsection{Confounders}

Analyses were adjusted for confounders which have previously shown to be a cause or plausible influence on maternal BMI, smoking and alcohol exposure and the offspring MIH outcome. The confounders adjusted for in the maternal and paternal analyses include age, education, parity (maternal), smoking (for BMI and alcohol analyses) and alcohol consumption (for BMI and smoking analyses). BMI, smoking, and alcohol were defined as above. Maternal and paternal age were kept as continuous variables. Parity was measured using data from the mother's questionnaire, answered at 18 weeks' gestation. We used questions regarding the mother's previous pregnancies, which asked how many times the mother had previously been pregnant. This was used to define parity as nulliparous and multiparous. Educational attainment was used as a proxy measure of parents' socioeconomic status. We used questions concerning educational qualifications for both the mothers, and their partners from the mother's questionnaire completed around 32 weeks' gestation. Educational attainment was classified into three categories, low (none/ CSE), medium (vocational/ O/ A level) and high (university degree). 
medRxiv preprint doi: https://doi.org/10.1101/2021.10.27.21265567; this version posted October 28, 2021. The copyright holder for this preprint (which was not certified by peer review) is the author/funder, who has granted medRxiv a license to display the preprint in perpetuity.

It is made available under a CC-BY-NC-ND 4.0 International license .

15,454 pregnant women and 15,589 known foetuses enrolled into ALSPAC as of February 2019

"My Teeth" questionaire aged $~ 7$ and had at least one first permanent molar tooth.

\section{Exclusions}

Children who did not complete the "My Teeth" questionnaire aged $\sim 7$ or did not have at least one first permanent molar tooth through.

$\mathrm{N}$ with maternal smoking (yes/no) data $=5,017$

$\mathrm{N}$ with paternal smoking (yes/no) data $=4,250$

$\mathrm{N}$ with maternal alcohol (yes/no) data $=4,384$

$\mathrm{N}$ with paternal alcohol (yes/no) data $=4,391$

Figure 2: Study flow diagram illustrating participant selection in the ALSPAC cohort. 
medRxiv preprint doi: https://doi.org/10.1101/2021.10.27.21265567; this version posted October $28,2021$. The copyright holder for this preprint (which was not certified by peer review) is the author/funder, who has granted medRxiv a license to display the preprint in It is made available under a CC-BY-NC-ND 4.0 International license .

\subsection{Statistical Analysis}

Analyses were conducted using R (Version 4.0.3). Analysis steps were discussed and agreed upon prior to any analyses taken place and documented in a pre-specified analysis plan (29). We used logistic regression with maximal numbers (i.e. numbers included in each model are likely to vary due to missing data on exposure/ outcome or confounders). All analyses were run unadjusted (model 1), confounder adjusted (model 2), and confounder adjusted with the addition of the other parent's exposure (BMI/ smoking/ alcohol consumption) (model 3). Model 3 produces a maternal association that adjusts for maternal confounders as well as the paternal exposure, and similarly a paternal association adjusting for paternal confounders and the maternal exposure, referred to as 'other parent adjusted'. The reason for mutual parent adjustment is that parental BMI, smoking and alcohol consumption may associate with one another through assortative mating, shared social and environmental background, and modelling for each other's behaviours (30).

For the negative control exposure analyses, all three models of analyses were performed, then maternal and paternal exposures were directly compared with MIH outcomes by observing point estimates and 95\% Confidence Intervals (CI)s. In the second part, the negative outcome analyses, the first two models of analyses were performed, then maternal exposures were directly compared with MIH and dental trauma (negative control) outcomes.

To assess for deviation from linearity in the BMI-MIH association, BMI was split into quintiles for mothers and fathers. This BMI quintile variable was treated as both continuous and categorical in logistic regression models. We report p-values for a linear trend.

We aimed to perform a sensitivity analysis defining cases as those that had affected FPMs and permanent incisors using the age 10 questionnaire. Analyses were also performed on complete cases (cases with no missing data on exposure, outcome, or confounders) to investigate the influence of missing data (missing data reported in Table S1). Complete case outcomes were compared with the main analyses, which is reported in the supplementary data (Table S2). 
medRxiv preprint doi: https://doi.org/10.1101/2021.10.27.21265567; this version posted October 28, 2021. The copyright holder for this preprint (which was not certified by peer review) is the author/funder, who has granted medRxiv a license to display the preprint in It is made available under a CC-BY-NC-ND 4.0 International license

\section{RESULTS}

\section{Participant characteristics}

Figure 2 shows selection of participants from the ALSPAC cohort into the study population.

Table 1 shows the distributions of offspring, maternal and paternal characteristics of the study population. Overall, a total of 5536 offspring had completed the dental questionnaires and had at least one first permanent molar tooth. The prevalence of offspring MIH was 5.4\% (Table 1). 40 of the 297 (18.8\%) MIH cases had both molars and incisors affected at age 10 . The prevalence of dental trauma was $13.5 \%$. Mean BMI was $22.3 \mathrm{~kg} / \mathrm{m}^{2}$ and $25.1 \mathrm{~kg} / \mathrm{m}^{2}$ for mothers and fathers, respectively. $21.4 \%$ of mothers smoked during pregnancy and $31.6 \%$ of fathers smoked around the time of pregnancy. $73.5 \%$ of mothers consumed any alcohol during pregnancy and $96.1 \%$ of fathers consumed any alcohol around the time of pregnancy. Missing data is summarised in Table S1 of the supplementary data. 
medRxiv preprint doi: https://doi.org/10.1101/2021.10.27.21265567; this version posted October $28,2021$. The copyright holder for this preprint (which was not certified by peer review) is the author/funder, who has granted medRxiv a license to display the preprint in It is made available under a CC-BY-NC-ND 4.0 International license.

Table 1: Participant characteristics

\begin{tabular}{|c|c|c|c|}
\hline & All & MIH & No MIH \\
\hline \multicolumn{4}{|l|}{ Offspring } \\
\hline Total N & 5536 & 297 & 5239 \\
\hline $\begin{array}{l}\mathbf{N}(\%) \text { MIH case } \\
\text { (molars only) }\end{array}$ & $297(5.4)$ & $297(100.0)$ & \\
\hline $\begin{array}{l}\text { N (\%) MIH sensitivity } \\
\text { (molars and incisors) }\end{array}$ & $40(0.7)$ & $40(18.8)$ & \\
\hline N (\%) Dental trauma & $621(13.5)$ & $0(0.0)$ & $621(14.4)$ \\
\hline \multicolumn{4}{|l|}{ Maternal } \\
\hline Mean (SD) age (years) & $29.5(4.5)$ & $29.2(4.6)$ & $29.53(4.5)$ \\
\hline Mean (SD) BMI $\left(\mathrm{kg} / \mathrm{m}^{2}\right)$ & $22.3(4.1)$ & $22.9(4.8)$ & $22.28(4.0)$ \\
\hline \multicolumn{4}{|l|}{ N (\%) Pregnancy Smoking } \\
\hline Trimester 1 & $988(18.2)$ & $67(23.0)$ & $921(18.0)$ \\
\hline Trimester 2 & $782(14.4)$ & $57(19.6)$ & $725(14.1)$ \\
\hline Trimester 3 & $747(15.1)$ & $50(19.5)$ & $697(14.9)$ \\
\hline Any smoking & $1072(21.4)$ & $73(27.3)$ & $999(21.0)$ \\
\hline \multicolumn{4}{|l|}{ N (\%) Pregnancy Alcohol } \\
\hline Trimester 1 & $3001(55.6)$ & $153(53.3)$ & $2848(55.7)$ \\
\hline Trimester 3 & $1074(35.0)$ & $47(29.7)$ & $1027(35.3)$ \\
\hline Any alcohol & $3224(73.5)$ & $166(70.9)$ & $3058(73.7)$ \\
\hline N (\%) Parity & $2841(53.0)$ & $152(52.8)$ & $2689(53.0)$ \\
\hline \multicolumn{4}{|l|}{ Education } \\
\hline Low: None/ CSE & $710(13.3)$ & $55(19.7)$ & $655(12.9)$ \\
\hline Medium: Vocational/ O/ A Level & $3713(69.7)$ & $184(65.9)$ & 3547 (69.9) \\
\hline High: Degree & $910(17.0)$ & $40(14.3)$ & $870(17.2)$ \\
\hline \multicolumn{4}{|l|}{ Paternal } \\
\hline Mean (SD) age (years) & $31.6(5.6)$ & $31.3(5.9)$ & $31.57(5.5)$ \\
\hline Mean (SD) BMI (kg/ m²) & $25.1(3.2)$ & $24.9(3.2)$ & $25.13(3.2)$ \\
\hline \multicolumn{4}{|l|}{ N (\%) Pregnancy Smoking } \\
\hline Any smoking & $1344(31.6)$ & $71(33.8)$ & $1273(31.5)$ \\
\hline \multicolumn{4}{|l|}{ N (\%) Pregnancy Alcohol } \\
\hline Any alcohol & $4219(96.1)$ & $205(95.3)$ & $4014(96.1)$ \\
\hline \multicolumn{4}{|l|}{ N (\%) Education } \\
\hline Low: None/ CSE & $996(19.1)$ & $65(24.3)$ & $931(18.8)$ \\
\hline Medium: Vocational/ O/ A- level & $3043(58.2)$ & $146(54.5)$ & $2897(58.4)$ \\
\hline High: Degree level & $1186(22.7)$ & $57(21.3)$ & $1129(22.8)$ \\
\hline
\end{tabular}

Distributions of offspring, maternal and paternal characteristics of the study population. Abbreviations: $\mathrm{N}=$ Number, $\mathrm{SD}=$ Standard deviation, $\mathrm{MIH}=$ Molar-incisor hypomineralisation, $\mathrm{BMI}=$ Body mass index, CSE $=$ Certificate of secondary education, Trimester $1=$ First 3 months of pregnancy, Trimester $2=18$ weeks' gestation, Trimester $3=32$ weeks' gestation . 
medRxiv preprint doi: https://doi.org/10.1101/2021.10.27.21265567; this version posted October 28, 2021. The copyright holder for this preprint (which was not certified by peer review) is the author/funder, who has granted medRxiv a license to display the preprint in It is made available under a CC-BY-NC-ND 4.0 International license

\section{BMI and offspring MIH}

In the confounder and other parent BMI-adjusted model (model 3), there was a $4 \%$ increased odds of offspring MIH for every unit $(1 \mathrm{~kg} / \mathrm{m} 2)$ increase in maternal BMI (OR: 1.04, 95\% CI: 1.00-1.08) (Table 2 and Figure 3A). In comparison, point estimates for paternal BMI were in the opposite direction (OR: 0.94, 95\% CI: 0.89, 1.00). Negative control outcome analyses for maternal BMI and offspring dental trauma showed no difference in odds, with point estimates around the null (OR: 0.99, 95\% CI: 0.96, 1.02) (Table S2 and Figure 3A). Results of complete case analyses were broadly consistent (Table S3). Taken together, these results provide some evidence of an association between mean maternal BMI and offspring MIH with negative control analyses suggesting that the results are unlikely to be being driven by unmeasured confounders. In analyses of BMI quintiles, we compared linear and categorical models. Whilst there was statistical evidence for a linear trend for maternal BMI (p-value for per fifth increase $=0.04$ ), Figure 3B shows that this appeared to be driven by the highest quintile. In comparison, there was no evidence of a positive association for any of the paternal BMI quintiles and offspring MIH (Figure 3B). 
medRxiv preprint doi: https://doi.org/10.1101/2021.10.27.21265567; this version posted October 28,2021 . The copyright holder for this preprint (which was not certified by peer review) is the author/funder, who has granted medRxiv a license to display the preprint in perpetuity.

It is made available under a CC-BY-NC-ND 4.0 International license.

\section{A: Continuous BMI}

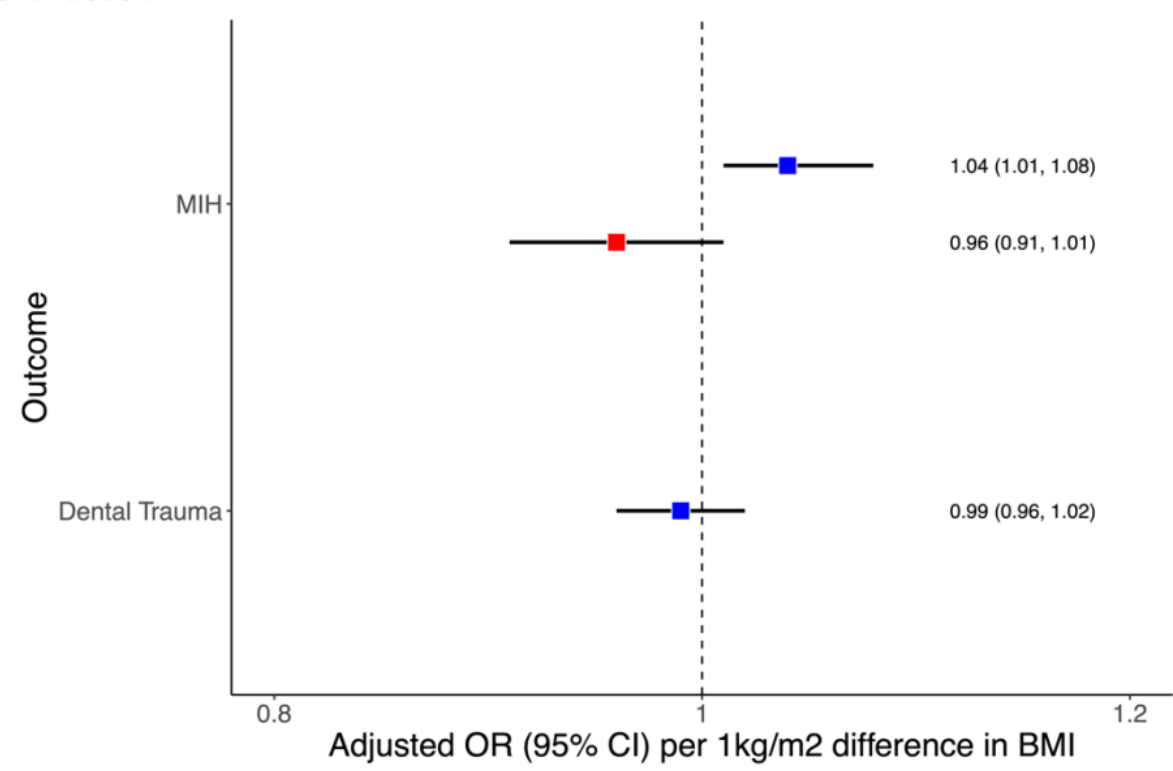

Exposure

- Maternal BMI

Paternal BMI

\section{B: BMI Quintiles}

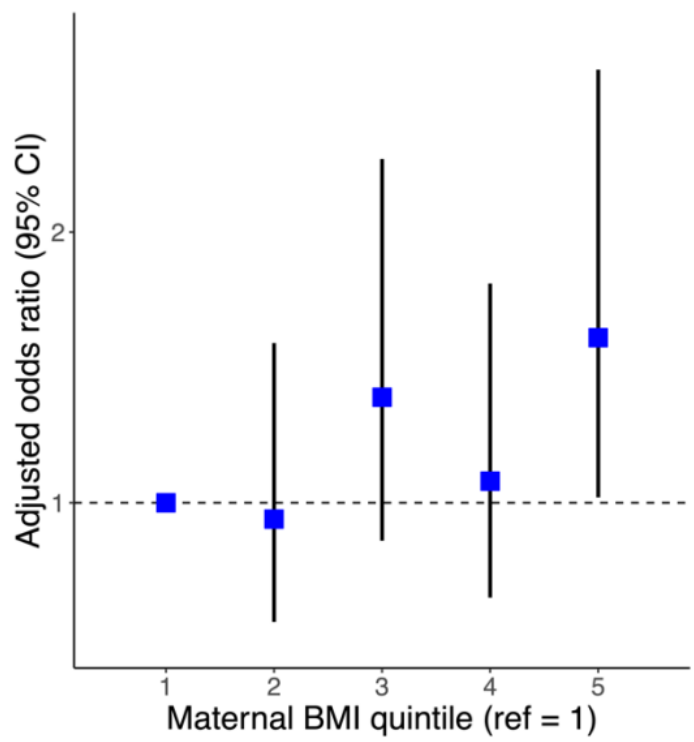

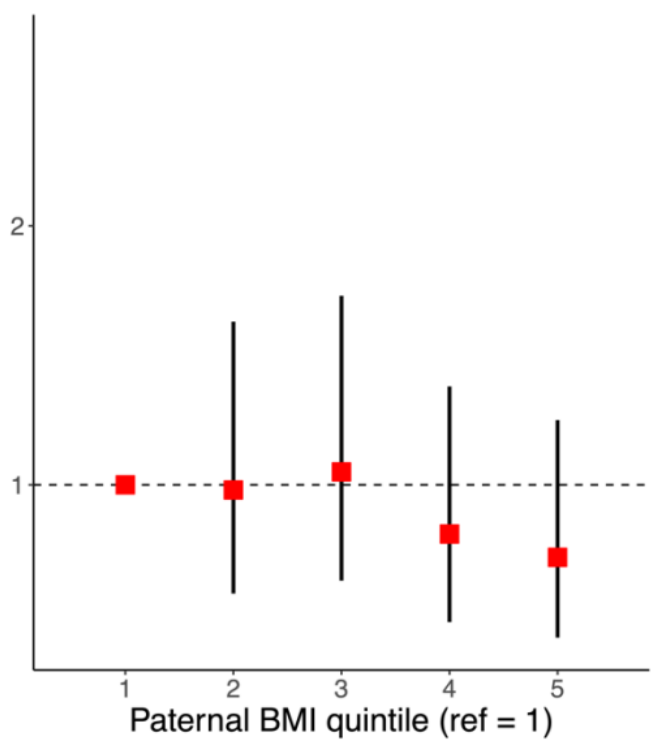

Figure 1: Confounder and other parent body mass index (BMI)-adjusted associations (model 3) for maternal and paternal BMI and offspring molar-incisor hypomineralisation (MIH). Confounders adjusted for include age, parity (maternal), education, pregnancy smoking, pregnancy alcohol consumption and the other parent's BMI. A shows the odds ratio and 95\% confidence intervals of offspring MIH or dental trauma for a 1-unit $(1 \mathrm{~kg} / \mathrm{m} 2)$ difference in maternal BMI (blue) and paternal BMI (red). B shows the confounder and other parent BMI-adjusted associations for maternal (red) and paternal BMI (blue) split into quintiles (fifths) and offspring MIH. Results are odds ratio and 95\% confidence intervals for BMI quintile and offspring MIH in comparison to BMI quintile 1. 
medRxiv preprint doi: https://doi.org/10.1101/2021.10.27.21265567; this version posted October $28,2021$. The copyright holder for this preprint (which was not certified by peer review) is the author/funder, who has granted medRxiv a license to display the preprint in It is made available under a CC-BY-NC-ND 4.0 International license.

\section{Smoking and offspring MIH}

Unadjusted associations showed maternal pregnancy smoking was associated with an increased odds of offspring MIH (OR: 1.41, 95\%CI 1.06, 1.86) (Table 2). However, after adjusting for confounders, the association attenuated to the null (model 2: OR: 0.98, 95\% CI: 0.68, 1.38; model 3: OR: 0.76, 95\%CI: 0.46, 1.22). Point estimates for paternal smoking were positively associated with MIH, but confidence intervals spanned the null (model 3: OR: 1.21, 95\%. CI: 0.82, 1.77). For the negative control outcome analyses (Table S2), confounder adjusted results similarly showed a small positive association between maternal smoking and offspring dental trauma, and confidence intervals included the null (OR: 1.20, 95\%CI: 0.93, 1.53). Taken together, these results provide no evidence of an intrauterine effect of maternal smoking and offspring MIH. In complete case analyses (Table S3), all estimates for maternal smoking (including the unadjusted model) were in line with the confounder adjusted main analysis.

\section{Alcohol consumption and offspring MIH}

Associations for alcohol consumption were largely imprecise and showed no clear evidence of an association in maternal (OR: $0.79,95 \% \mathrm{CI}: 0.56,1.21)$ or paternal confounder and other parent adjusted models (OR: 1.04 95\% CI: 0.41, 3.47) (Table 2). In comparison, negative control outcome analyses with dental trauma (Table S2) showed no clear evidence of an association with maternal pregnancy alcohol consumption, and similarly confidence intervals spanned the null (OR: 0.94, 95\% CI 0.75, 1.18). 
medRxiv preprint doi: https://doi.org/10.1101/2021.10.27.21265567; this version posted October 28,2021 . The copyright holder for this preprint (which was not certified by peer review) is the author/funder, who has granted medRxiv a license to display the preprint in perpetuity.

It is made available under a CC-BY-NC-ND 4.0 International license .

Table 2: Negative control exposure analyses

\begin{tabular}{|c|c|c|c|}
\hline BMI & $\begin{array}{c}\text { Model } 1 \\
\text { OR }(95 \% \text { CI) }\end{array}$ & $\begin{array}{c}\text { Model } 2 \\
\text { OR }(95 \% \text { CI) }\end{array}$ & $\begin{array}{c}\text { Model 3 } \\
\text { OR }(95 \% \text { CI })\end{array}$ \\
\hline Maternal BMI & $1.03(1.00-1.06)$ & $1.04(1.00-1.07)$ & $1.04(1.00-1.08)$ \\
\hline$N$ Total & 4830 & 3582 & 2698 \\
\hline$N$ Case & 252 & 184 & 134 \\
\hline Paternal BMI & $0.97(0.92-1.01)$ & $0.96(0.91-1.01)$ & $0.94(0.89-1.00)$ \\
\hline$N$ Total & 3993 & 2968 & 2713 \\
\hline N Case & 202 & 142 & 128 \\
\hline \multicolumn{4}{|l|}{ Smoking } \\
\hline Maternal Smoking & $1.41(1.06,1.86)$ & $0.98(0.68,1.38)$ & $0.76(0.46,1.22)$ \\
\hline$N$ Total & 5017 & 4025 & 3184 \\
\hline$N$ Case & 267 & 210 & 151 \\
\hline Paternal Smoking & $1.11(0.82,1.48)$ & $1.16(0.81,1.64)$ & $1.21(0.82,1.77)$ \\
\hline N Total & 4250 & 3270 & 3061 \\
\hline N Case & 210 & 155 & 144 \\
\hline \multicolumn{4}{|l|}{ Alcohol } \\
\hline Maternal Alcohol & $0.87(0.65-1.17)$ & $0.87(0.64-1.18)$ & $0.79(0.56-1.12)$ \\
\hline N Total & 4384 & 4025 & 3288 \\
\hline$N$ Case & 234 & 210 & 155 \\
\hline Paternal Alcohol & $0.83(0.45-1.70)$ & $1.03(0.48-2.67)$ & $1.04(0.41-3.47)$ \\
\hline$N$ Total & 4391 & 3270 & 2666 \\
\hline$N$ Case & 215 & 155 & 127 \\
\hline \multicolumn{4}{|c|}{$\begin{array}{l}\text { Negative control exposure analyses showing associations between maternal and paternal exposure } \\
\text { (pre-pregnancy BMI, pregnancy smoking and alcohol consumption) with offspring MIH. Results of } \\
\text { univariable and multivariable logistic regression analyses shown as odds ratio (OR) and 95\% } \\
\text { Confidence intervals (95\% CI). Model } 1=\text { unadjusted, Model } 2=\text { confounder adjusted: age } \\
\text { education, parity (maternal), pregnancy smoking (BMI and alcohol analyses) and alcoho } \\
\text { consumption (BMI and smoking analyses), Model } 3=\text { adjusted for the same confounders as model } 2 \\
\text { and additionally for the other parent's exposure during/around pregnancy. }\end{array}$} \\
\hline
\end{tabular}


medRxiv preprint doi: https://doi.org/10.1101/2021.10.27.21265567; this version posted October 28,2021 . The copyright holder for this preprint (which was not certified by peer review) is the author/funder, who has granted medRxiv a license to display the preprint in It is made available under a CC-BY-NC-ND 4.0 International license .

\section{DISCUSSION}

In this prospective cohort study, we found evidence of a possible small intrauterine effect between maternal pre-pregnancy BMI and offspring MIH. Additional investigations uncovered that this association appeared to be non-linear and may be driven by a threshold effect in the highest BMI quintile. We did not find similar associations in our negative control analyses, suggesting that these results are unlikely to be explained by confounding. We found no robust evidence to suggest a causal intrauterine effect of maternal pregnancy smoking or alcohol consumption on offspring MIH. Although, we acknowledge that these results were less precise. To our knowledge, this is the first study to use prospective data in large numbers using negative control analyses to explore possible maternal pregnancy risk factors for offspring $\mathrm{MIH}$.

Our results suggested that mothers with a higher BMI have increased odds of having an offspring with MIH. There are several potential explanations for this association with maternal BMI. Firstly, dental development of FPMs develop in utero, therefore it is biologically plausible that maternal pre-pregnancy BMI (which is reflective of weight during early pregnancy) may influence MIH. Pre-pregnancy obesity provides an unfavourable environment for foetal development due to supply of nutrients crossing the placenta in deficit or overabundance $(16,17)$. This may cause metabolic and physiological changes which alter growth and development $(16,17)$. A second explanation is that we have not fully accounted for confounders. However, in this study we did attempt to include stringent confounder adjustments and negative control analyses investigations in which our results do not support presence of confounding. Finally, the finding could be a false positive (due to chance). As this is the first study to investigate pre-pregnancy BMI as a potential risk factor for MIH it cannot be compared with previous work. More research with larger studies are warranted to attempt to replicate the association with BMI and to assess the effects of obese and severely obese World Health Organisation categories. If true, our findings would have implications to further support encouragement of a healthy pre-pregnancy BMI in women trying to conceive.

We did not find evidence of an association between maternal pregnancy smoking and offspring MIH. Although unadjusted findings revealed an increased odds of offspring MIH in mothers who smoked, these odds were attenuated close to null after adjusting for confounders. However, these associations were imprecise, therefore we cannot simply reject 
medRxiv preprint doi: https://doi.org/10.1101/2021.10.27.21265567; this version posted October 28,2021 . The copyright holder for this preprint (which was not certified by peer review) is the author/funder, who has granted medRxiv a license to display the preprint in It is made available under a CC-BY-NC-ND 4.0 International license .

the possibility of an association between pregnancy smoking and offspring MIH. As these results had limited statistical power, negative control explorations were less meaningful. Our findings support findings of systematic reviews, that there is little evidence for an association between pregnancy smoking on offspring $\operatorname{MIH}(21,22)$. A recent well-powered case-control study, not included in these reviews, found evidence of an association between pregnancy smoking and offspring MIH (31); however, their exposure data was collected retrospectively, and is therefore susceptible to information bias (32). They also did not account for the range of confounders we have included here (e.g. parity and alcohol consumption) which in our study contributed to the full attenuation of the smoking effect on MIH.

Point estimates for maternal alcohol consumption were in the protective direction on offspring MIH, but these findings were imprecise. Therefore, no clear evidence of an association was found, and negative control explorations were not required to explore residual confounding. A protective association seems unlikely as there is no plausible biological explanation. Only two other studies $(14,33)$, have investigated the effect of pregnancy alcohol consumption on MIH. These lacked statistical power, had retrospective designs and conflicting findings. Therefore, the effects of alcohol consumption on MIH remain unclear.

A key strength of this study is the use of prospective cohort data which limits recall bias, compared to the majority of studies in this field which have used retrospective study designs, in which recall bias may influence results. Other strengths of this study include the adjustment of a wide range of prospectively measured, relevant confounders, and the use of negative control analyses to detect any residual confounding, which no previous study has accounted for. Taken together, these steps improved robustness of this study, which strengthens the evidence of our findings.

An important limitation is that maternal, paternal and offspring data were self-reported. Pregnant women may underreport their smoking and drinking habits because of social stigma. However, this under-reporting should not be correlated with MIH status due to the prospective nature of the study design, and would be expected to weaken any true effect of these exposures towards the null rather than create false positives. Furthermore, our MIH definition, "6-year molars that came through brown" at age 7, may be oversimplistic in comparison to the gold standard EAPD classification (1) which most other studies have used. 
medRxiv preprint doi: https://doi.org/10.1101/2021.10.27.21265567; this version posted October 28,2021 . The copyright holder for this preprint (which was not certified by peer review) is the author/funder, who has granted medRxiv a license to display the preprint in It is made available under a CC-BY-NC-ND 4.0 International license .

Our MIH cases may also include differentials that affect all teeth, such as amelogenesis imperfecta, fluorosis and enamel hypoplasia (34). This definition and self-reporting may result in misclassification of $\mathrm{MIH}$; however, this will be non-systematic with respect to the exposures and would, at worst, attenuate the magnitude of any association towards the null. Despite this uncertainty in our diagnosis, the prevalence of MIH was 5.4\%, which still lies within the reported range, 2.4 to $40.2 \%$ (8), but respectively at the lower end. We intended to prevent misclassification by conducting a sensitivity analysis, including cases with affected molars and incisors. However, with the sample size being small (40/297, 18.8\%), additional analyses would not have been particularly informative.

Another important consideration the use of negative control analyses; although negative controls are useful, a limitation of this method is that if an association is found with the presence of unmeasured confounding, we cannot specifically know what the confounding may be (35). This is because this method only detects the presence of confounding, and is therefore considered a "blunt tool" (23).

Overall, this study adds to the limited evidence investigating the effects of modifiable maternal risk factors on offspring MIH. This is beneficial, as previous research primarily focuses on non-modifiable risk factors such as maternal and childhood illnesses $(21,22)$, for which intervention is difficult. As the aetiology of MIH is likely to be multifactorial, future research exploring modifiable maternal risk factors, such as BMI, smoking and alcohol consumption, may enable preventative strategies or remove stigma from mothers of children with MIH. To improve comparability and accuracy, it is advisable for future studies to use prospectively obtained data with larger samples, clinically diagnose MIH using the EAPD criteria (1), adjust for relevant confounding variables, and use epidemiological methods to improve causality (eg. negative control analyses) as this present study has. As large enough sample sizes may be difficult to obtain, cross-cohort studies may be an alternative approach to gain sufficient statistical power.

\section{CONCLUSION}

In conclusion, these findings suggest that an association between higher maternal prepregnancy BMI and offspring MIH may exist. We did not find robust evidence for an effect of maternal pregnancy smoking or alcohol consumption on risk of offspring MIH. Further 
medRxiv preprint doi: https://doi.org/10.1101/2021.10.27.21265567; this version posted October 28, 2021. The copyright holder for this preprint (which was not certified by peer review) is the author/funder, who has granted medRxiv a license to display the preprint in It is made available under a CC-BY-NC-ND 4.0 International license.

studies with larger numbers utilising prospectively collected data with advanced epidemiological methods are required to replicate and further investigate these findings. Furthermore, exploring possible mechanisms that link the pregnancy environment to offspring MIH could identify targets for interventions for its prevention. 
medRxiv preprint doi: https://doi.org/10.1101/2021.10.27.21265567; this version posted October 28,2021 . The copyright holder for this preprint (which was not certified by peer review) is the author/funder, who has granted medRxiv a license to display the preprint in It is made available under a CC-BY-NC-ND 4.0 International license .

\section{REFERENCES}

1. Weerheijm KL. Judgement criteria for molar incisor hypomineralisation (MIH) in epidemiologic studies: a summary of the European meeting on MIH held in Athens, 2003. . European Journal of Paediatric Dentistry. 2003; 4:110-3.

2. Schmalfuss A, Stenhagen KR, Tveit AB, Crossner CG, Espelid I. Canines are affected in 16-year-olds with molar-incisor hypomineralisation (MIH): an epidemiological study based on the Tromsø study: "Fit Futures". Eur Arch Paediatr Dent. 2016; 17(2):107-13.

3. Bullio Fragelli CM, Jeremias F, Feltrin de Souza J, Paschoal MA, de Cássia Loiola Cordeiro R, Santos-Pinto L. Longitudinal Evaluation of the Structural Integrity of Teeth Affected by Molar Incisor Hypomineralisation. Caries Res. 2015; 49(4):378-83.

4. Americano GCA, Jacobsen PE, Soviero VM, Haubek D. A systematic review on the association between molar incisor hypomineralization and dental caries. International Journal of Paediatric Dentistry. 2017; 27(1):11-21.

5. Jälevik B, Möller M. Evaluation of spontaneous space closure and development of permanent dentition after extraction of hypomineralized permanent first molars. Int $\mathbf{J}$ Paediatr Dent. 2007; 17(5):328-35.

6. Jälevik B, Klingberg GA. Dental treatment, dental fear and behaviour management problems in children with severe enamel hypomineralization of their permanent first molars. Int J Paediatr Dent. 2002; 12(1):24-32.

7. Kotsanos N, Kaklamanos EG, Arapostathis K. Treatment management of first permanent molars in children with Molar-Incisor Hypomineralisation. Eur J Paediatr Dent. 2005; 6(4):179-84.

8. Schwendicke F, Elhennawy K, Reda S, Bekes K, Manton DJ, Krois J. Global burden of molar incisor hypomineralization. Journal of Dentistry. 2018; 68:10-8.

9. Jeremias F, Pierri RA, Souza JF, Fragelli CM, Restrepo M, Finoti LS, et al. FamilyBased Genetic Association for Molar-Incisor Hypomineralization. Caries Res. 2016; 50(3):310-8.

10. Vieira AR, Kup E. On the Etiology of Molar-Incisor Hypomineralization. Caries Research. 2016; 50(2):166-9.

11. Schuurs A. Pathology of the Hard Dental Tissues. 1 ed: Wiley-Blackwell; 2012.

12. Welbury R, Duggal MS, Hosey MT. Paediatric dentistry. 5 ed. Oxford: Oxford University Press; 2018. 
medRxiv preprint doi: https://doi.org/10.1101/2021.10.27.21265567; this version posted October 28,2021 . The copyright holder for this preprint (which was not certified by peer review) is the author/funder, who has granted medRxiv a license to display the preprint in It is made available under a CC-BY-NC-ND 4.0 International license .

13. Ghanim A, Manton D, Bailey D, Marino R, Morgan M. Risk factors in the occurrence of molarincisor hypomineralization amongst a group of Iraqi children. International Journal of Paediatric Dentistry. 2013; 23(3):197-206.

14. Pitiphat W, Luangchaichaweng S, Pungchanchaikul P, Angwaravong O, Chansamak N. Factors associated with molar incisor hypomineralization in Thai children. European Journal of Oral Sciences. 2014; 122(4):265-70.

15. Arrow P. Risk factors in the occurrence of enamel defects of the first permanent molars among schoolchildren in Western Australia. Community Dentistry and Oral Epidemiology. 2009; 37(5):405-15.

16. Leddy MA, Power ML, Schulkin J. The impact of maternal obesity on maternal and fetal health. Rev Obstet Gynecol. 2008; 1(4):170-8.

17. Maffeis C, Morandi A. Effect of Maternal Obesity on Foetal Growth and Metabolic Health of the Offspring. Obes Facts. 2017; 10(2):112-7.

18. Little J, Cardy A, Munger RG. Tobacco smoking and oral clefts: a meta-analysis. Bull World Health Organ. 2004; 82(3):213-8.

19. Sant'Anna LB, Tosello DO. Fetal alcohol syndrome and developing craniofacial and dental structures--a review. Orthod Craniofac Res. 2006; 9(4):172-85.

20. Mukherjee RA, Hollins S, Turk J. Fetal alcohol spectrum disorder: an overview. J R Soc Med. 2006; 99(6):298-302.

21. Silva MJ, Scurrah KJ, Craig JM, Manton DJ, Kilpatrick N. Etiology of molar incisor hypomineralization - A systematic review. Community Dentistry and Oral Epidemiology. 2016; 44(4):342-53.

22. Fatturi AL, Wambier LM, Chibinski AC, Assuncao LRD, Brancher JA, Reis A, et al. A systematic review and meta-analysis of systemic exposure associated with molar incisor hypomineralization. Community Dentistry and Oral Epidemiology. 2019; 47(5):407-15.

23. Lipsitch M, Tchetgen Tchetgen E, Cohen T. Negative controls: a tool for detecting confounding and bias in observational studies. Epidemiology. 2010; 21(3):383-8.

24. Gage SH, Munafò MR, Davey Smith G. Causal Inference in Developmental Origins of Health and Disease (DOHaD) Research. Annu Rev Psychol. 2016; 67:567-85.

25. Taylor K, Elhakeem A, Nader JLT, Yang T, Isaevska E, Richiardi L, et al. The effect of maternal pre-/early-pregnancy BMI and pregnancy smoking and alcohol on congenital heart diseases: a parental negative control study. medRxiv. 2020. 
medRxiv preprint doi: https://doi.org/10.1101/2021.10.27.21265567; this version posted October $28,2021$. The copyright holder for this preprint (which was not certified by peer review) is the author/funder, who has granted medRxiv a license to display the preprint in It is made available under a CC-BY-NC-ND 4.0 International license .

26. Brand JS, Gaillard R, West J, McEachan RRC, Wright J, Voerman E, et al. Associations of maternal quitting, reducing, and continuing smoking during pregnancy with longitudinal fetal growth: Findings from Mendelian randomization and parental negative control studies. PLoS Med. 2019; 16(11):e1002972.

27. Boyd A, Golding J, Macleod J, Lawlor DA, Fraser A, Henderson J, et al. Cohort Profile: the 'children of the 90s'--the index offspring of the Avon Longitudinal Study of Parents and Children. Int J Epidemiol. 2013; 42(1):111-27.

28. Fraser A, Macdonald-Wallis C, Tilling K, Boyd A, Golding J, Davey Smith G, et al. Cohort Profile: the Avon Longitudinal Study of Parents and Children: ALSPAC mothers cohort. Int J Epidemiol. 2013; 42(1):97-110.

29. Taylor K, Lim Q-Y, Dudding T. Exploring Maternal Risk Factors for Offspring Molar Incisor Hypomineralisation Open Science Framework (OSF)2021 [Available from: https://osf.io/6kasc/ [Accessed 25.10.2021].

30. Sharp GC, Lawlor DA. Paternal impact on the life course development of obesity and type 2 diabetes in the offspring. Diabetologia. 2019; 62(10):1802-10.

31. Lee DW, Kim YJ, Oh Kim S, Choi SC, Kim J, Lee JH, et al. Factors Associated with Molar-Incisor Hypomineralization: A Population-Based Case-Control Study. Pediatr Dent. 2020; 42(2):134-40.

32. Sutton-Tyrrell K. Assessing bias in case-control studies. Proper selection of cases and controls. Stroke. 1991; 22(7):938-42.

33. F R. Molar-incisor hypomineralization in schoolchildren of São Luis, Brazil Maranhão: prevalence and associated factors. 2015; 15:271-8.

34. Almuallem Z, Busuttil-Naudi A. Molar incisor hypomineralisation (MIH) - an overview. British Dental Journal. 2018; 225(7):601-9.

35. Sanderson E, Macdonald-Wallis C, Davey Smith G. Negative control exposure studies in the presence of measurement error: implications for attempted effect estimate calibration. Int J Epidemiol. 2018; 47(2):587-96. 